\title{
MIHAJLO PUPIN: PUTNIK, PISAC, INOVATOR
}

Poznati naučnik srpskog porekla Mihajlo Pupin doselio se u Ameriku 18\%4. godine. Osim svojih dostignuća u nauci, u oblasti telekomunikacija i istaknutog mesta profesora, a kasnije i počasnog profesora na Univerzitetu Kolumbija u Njujorku, osvojio je uglednu Pulicerovu nagradu za autobiografski roman, Od pašnjaka do naučenjaka, 1924. godine. Pulicerova nagrada dodeljuje se godišnje za najbolje ostvarenje u oblasti književnosti, drame i muzike u okviru SAD. Ovaj esej bavi se Pupinovim delom u kontekstu njegovog životnog puta doseljenika, naučnika i pisca. U eseju se analizira Pupinova autobiografija koja je napisana u tada avangardnom maniru lične proze, koji je Pupinu omogućio uporedno sagledavanje i narativno slikanje njegove dve otadžbine: Srbije i Amerike.

Ključne reči: Banat, Amerika, nauka, zvuk, ,grinhorn”, identitet, hibridnost, autofikcija.

Katedra za anglistiku Filološkog fakulteta Univerziteta u Beogradu ima dugu tradiciju proučavanja kulturnih veza između anglofonskih kulturnih prostora i zemalja Balkana. Tako prof. dr Veselin Kostić (1972) piše o vezama između jugoslovenskih zemalja do 1700, prof. dr. Slobodan Vukobrat (1992, 1997) piše o englesko-srpskim književnim vezama, a prof. dr Svetozar Ignjačević (1994, 2000) slaže komadiće „izlomljenog ogledala” stvarajući portret jugoslovenskih i šire balkanskih prostora u rukopisima anglofonih autora sa kraja devetnaestog i početka dvadesetog veka. ${ }^{1}$ Sva ova studijska istraživanja koja obuhva-

1 Veselin Kostić, Kulturne veze izmedu jugoslovenskih zemalja i Engleske do 1700, Beograd: SANU, 1972. / Slobodan Vukobrat, Englesko-srpske književne veze, Beo- 
taju ogromnu arhivsku građu tekstova o „nama” i „njima” vode u krajnjem ishodu do stvaranja fiktivnih portreta opisa prostora iz mašte i pera putnika, pisaca, lekara ili namernika. Ovi putopisi predstavljaju svedočanstva o tradiciji uspostavljanja veza između različitih kulturnih grupa kao i izvor obaveštenja i priča o nepoznatim prostorima. Iz ovih putopisa je izranjala slika o Drugom.

Dvadeseti vek, vek putovanja, migracija, „kulturna izmeštenost” (Bнавна 1992: 141) donosi novi način istraživanja, razmišljanja i književnog uobličavanja Drugog, kao i potpuno novo razumevanje prostora i identiteta. Putnici-autori-putopisci doživljavaju nove prostore kao deo sopstvenog iskustva stvarnosti, a ne kao isključivo mapiranje nepoznatih predela.

Tako, imigrantske književnosti crpu svoja specifična značenja iz prilika u kojima su nastale i okolnosti koje su profilisale specifičnu kulturu migranata. Naime, specifičnost ovog umetničkog polja jeste u večitom preplitanju naracija „sveta” i „doma” jer, „samo izmeštanje zatire jasnu graničnu liniju između doma i sveta" (IBID). Putnici sagledavaju nove prostore na osnovu usvojenih paradigmi, na osnovu sopstvenog iskustva „doma” kao najstarijeg i najvažnijeg u svakoj psihi. Istovremeno, posmatraju svoj dom u sećanju na osnovu novog iskustva stvarnosti i u saglasju sa novim životom u stranoj sredini.

Na taj način, slike o drugim prostorima i drugim kulturama, usled sve češćih putovanja, predstavljaju rezultat uključivanja raznih agenasa i mešanja iskustava stvarnosti i sveta. Svedočanstva o kulturnim vezama između različitih kultura dobijaju obeležja globalne kulturne hibridnosti. Slika o Drugom upotpunjava sopstveni odraz u ogledalu.

U svetlu ovih društvenih i kulturnih događaja i stilova sa kraja devetnaestog i početka dvadesetog veka nastaje književna „slika” Balkana iz pera i mašte velikog srpskog naučnika Mihajla Pupina. Pupin je stvara u svojoj autobiografiji, Od pašnjaka do naučenjaka (1924). Pupin, naime, piše o svoje dve domovine, Srbiji i Americi, o tome kako

grad: Naučna knjiga i Filološki fakultet, 1992; 1997. / Svetozar Ignjačević, Zemlja čuda u izlomljenom ogledalu; Zemlja čuda u izlomljenom ogledalu (ponovo), Beograd: DBR; Narodna knjiga, 1994; 2000. 
je otišao iz jedne, a zatim nakon mnogo muka i neizvesnosti prigrlio drugu otadžbinu. Pišući o odrastanju, sazrevanju i razmšljanjima u toku svog životnog puta, Pupin stvara svojevrsne književne portrete oba prostora.

Pupin je rodjen u Idvoru u Banatu u oktobru 1854. Roditelji su mu bili srpske nacionalnosti. Iako su bili neuki, podsticali su ga na učenje, obrazovanje i napredovanje, a posebno majka. Ohrabren majčinim podsticajima, uverenjima i saznanjima i sopstvenom željom za napretkom, Pupin napušta svoje rodno selo i nakon kratkotrajih boravaka u obližnjem Pančevu i Pragu, putuje u Ameriku da tamo „sakupi veliko bogatstvo znanja”. Pupin se u Americi obreo u osvit dvadesetog veka, 1874. godine. Nakon perioda lutanja i traganja za svojim mestom u novoj sredini studira na Univerzitetu Kolumbija u Njujorku gde je 1883. godine diplomirao. Iste godine je postao američki državljanin. Kasnije je Pupin nastavio studije na Univerzitetu u Kembridžu i Univerzitetu u Berlinu, na kome je odbranio doktorsku disertaciju 1889. godine. Predavao je matematičku fiziku na Univerzitetu Kolumbija, a 1931. godine dobio je zvanje počasnog profesora. Pupin je tvorac mnogih inovacija iz oblasti telekomunikacija. Najpoznatiji je po patentima iz oblasti telefonije koji su višestruko unapredili telegrafski i telefonski prenos.

Nekoliko decenija posle dolaska u Ameriku, kad je već umnogome ostvario majčine i sopstvene snove, kao uspešan naučnik, profesor i cenjeni građanin Amerike Pupin opisuje svoj životni put i put sticanja znanja. Pupin piše svoje autobiografsko delo 1924. godine. Povezavši se sa novom kulturom i zemljom, Pupin je stekao i privilegiju da sagleda ova dva prostora kao svoja.

Pupin piše o svoje dve otadžbine, Americi i Srbiji, na način koji će nekoliko decenija kasnije formulisati slavni pisac i putnik, Salman Ruždi:

Naš identitet je istovremeno mnogostruk i pojedinačan. Ponekad verujemo da premošćujemo dve kulture, a ponekad da padamo između dve stolice. Ali bez obzira koliko je to tlo klizavo i opasno, za pisca je veoma plodno. Ako je književnost bar delimično pronalaženje novih perspektiva iz kojih je moguće 
razotkriti stvarnost, upravo u tom slučaju, naša udaljenost, geografska dislociranost, može nam pomoći da je pronađemo. ${ }^{2}$ (Rushdie 1991: 15)

Slika o dva „sopstvena” prostora je i poznata i nepoznata, ona je uvek sagledana i proživljena kao istovremeno prisutna i kao udaljena sećanjem. Kao i Ruždi mnogo godina kasnije, Pupin razume da pogled useljenika sublimira dvostruku perspektivu drugog, budući da je svaki useljenik i izvan i unutar obe svoje domovine, i one iz koje je potekao i one u koju je stigao. Sasvim u skladu sa Ruždijevim rečima, Pupin u uvodnim napomenama svoje autobiografije piše da „ima prilika koje padaju u oči useljeniku, dok izmiču pogledu sinova neke zemlje” ${ }^{3}$, shvatićemo koliko je bliska perspektiva stvarnosti svih, prostorno i vremenski udaljenih autora-migranata.

Ruždi naziva svoju rodnu Indiju „Indij[om] u mašti”, a na drugom mestu kaže „moja Indija” ili „imaginarna domovina”. ${ }^{4}$ Iseljenici, kaže Ruždi, žele da ponovo stvore sliku svoje domovine, da je opišu u pripovednom delu, „da stvore fikciju... [domovinu] u mašti” (1991: 10). Na sličan način, u svom delu Pupin stvara sliku Banata sećajući se svog detinjstva i mladosti u Idvoru.

Pupinova priča sastoji se od niza anegdota o seoskom životu, odrastanju i ljudima koji su obeležili taj deo njegovog života. Pomoću tih naracija-anegdota Pupin slika srpsko društvo banatskog sela sa kraja devetnaestog veka. Protagonisti Pupinove priče o otadžbini su učitelj, otac i majka i ostali seoski žitelji za koje su bile vezane nara-

2 Our identity is at once plural and partial. Sometimes we feel that we straddle two cultures; at other times, that we fall between two stools. But however ambiguous and shifting this ground may be, it is not an infertile territory for a writer to occupy. If literature is in part the business of finding new angles at which to enter reality, then once again our distance, our long geographical perspective, may provide us with such angles.

3 Knjiga Sa pašnjaka do naučenjaka objavljena je prvi put na engleskom jeziku 1924. godine. U prevodu na srpski jezik, iz pera M. Jevtića, objavljena je 1929. godine u izdanju Matice srpske iz Novog Sada.

4 India of the mind (10); my India (10); imaginary homeland (10). Reč je o eseju "Imaginary Homelands" (Imaginarne domovine), iz 1981. godine, u kome Salman Ruždi govori o sećanju na Indiju iz koje je emigrirao nekoliko decenija ranije. 
cije iz njegovog sećanja. Iz ovih priča izranjaju slike seoskog života, svakodnevice, običaja i durštvenog ponašanja. Priče dočaravaju duh banatskog sela, pobožnost, poštovanje koje su članovi zajednice negovali, starosnu hijerearhiju, ljubav prema prošlosti i nacionalnim mitovima, društveno uređenje, ulogu žena u zajednici, način saznavanja sveta, odnos prema istoriji, religiji i obrazovanju, privredivanje, ambicije, društvene vrednosti, i konačno ljubav i pravdoljubivost kao osnov etičke matrice srpskog društva.

Jedan od najilustrativnijih opisa seoskog života iz Pupinovog teksta svakako je slika seoskog posela. Guslar i pripovedač, ključna figura posela, Baba Batikin, jedan je od najupečatljivijih likova Pupinove Vojvodine. Baba Batikin uživao je veliko poštovanje i divljenje, bio arhetipski pripovedač, mudri starac. Baba Batikin bio je junak idvorskih posela, na osnovu toga što ga je krasio „izvanredan pripovedački dar”, a kad bi se umorio od poučnih priča „deklamovao [bi] junačke pesme” (Pupin 1929: 9) i u životu održavao stara srpska predanja. Donosio je novosti iz „velikog sveta” i budio znatiželju stanovnika malog banatskog sela. Autoritet je stekao jer je i sam bio učesnik istorijskih događaja - ratova i političkih pregovora, a poznavao je i velikog srpskog junaka Karađorđa, „priče o Karđorđu, na ovim poselima, uvek bi izazvale više oduševljenja nego sve njegove druge zanosne priče” (IBID).

Divljenje seljana poticalo je i od činjenice da je kao vojnik bio na dalekim mestima o kojima su seljani imali samo nejasnu predstavu:

[Baba Batikin] je bio u bitci kod Asperna, kada je Austrija tukla Napoleona. Imao je jedno veliko carsko odlikovanje, radi koga je bio osobito gord. Išao je i u Rusiju, sa jednom austrijskom divizijom za vreme Napoleonovog pohoda 1812. (IBID)

Častan vojnik Babi Batikin bio je i istinski „srpski minstrel” (IBID). Poput minstrela, Baba Batikin bio je glasnik i stvaralac, pripovedač istorije i fikcije. Pripovedao je kako o svojim vojnim podvizima i pohodima, tako i o avanturama koje je zamišljao, ,protiv Fridriha Velikog, o kojima mu je pričao njegov otac" (IBID). Ovenčan iskustvom i mudrošću bio je za mladog Pupina „prvi i najbolji učitelj istorije” (PuPIN 1929: 10). 
Ličnost Babe Batikina, kao i njegove priče, bili su refleksija kolektivnog duha njegove publike koja je bila sklona zajedničkim radovanjima, divljenjima i strahovima. Podstaknut divljenjem svoje publike, Baba Batikin se nikad ne bi umorio pričajući o njegovim junačkim borbama sa Turcima (Pupin 1929: 9). Priče o junaštvu, pravdi, vojničkoj časti dolazile su kao potvrda kolektivne predstave o društvenim vrednostima kojoj su se povinovali bez razlike.

Baba Batikin, minstrel i mudrac, u svojim fiktivnim izletima slikao je sistem vrednosti srpskog društva, osobine koje je tadašnja zajednica najviše cenila, junaštvo i pravdu. Baba Batikin pripovedao je o istoriji, Kraljeviću Marku i Karađorđu, koga je lično poznavao. Karađorđe, veliki srpski junak, služio je kao primer junaštva, dok je Kraljević Marko „bio pravi zatočnik prava i pravde” (PupIN 1929: 10). Njegovi megdani bili su megdani snažnog i hrabrog čoveka, koji brani slabe i potištene. Bio je častan i nimalo pohlepan. Marko se nikad nije borio da osvaja zemlju i gradove (IBID). Pravdoljubiv i velikodušan, njegov lik u kolektivnoj predstavi Batikinove publike ovaplotio bi osobine koje su bile njihov ideal.

Posela su bila prozor u svet, način da seljani saznaju vesti i dobiju širu sliku o svetu koju bi zatim sagledali i razumeli u skladu sa sopstvenim iskustvom stvarnosti: „U to vreme se taman bio završio Građanski rat u Americi. I kad god bi Baba Batikin spomenuo ime Linkolnovo, pomišljao sam da je to američki Kraljević Marko" (IBID).

Posela su stoga bila za mlade škola života, stvarajući prizmu kroz koju će naučiti da posmatraju svet. Istovremeno, bila su podstrek srpskom narodu da istraje u pravdi i istini uprkos teškoćama i da ne gubi veru u život. Slava opevanih junaka bila je svetlo u teškom i siromašnom životu. Pupin piše da su „utisci sa ovih sela bili duševna hrana koja je u mojoj duši oživela i održala osećanje: da je borba za pravo, pravdu i slobodu najplemenitija i najuzvišenija stvar na ovom svetu" (IBID). Tako, opisujući posela, ambijent i prostor u kome su se odvijala, Pupin govori o kulturi i istoriji istovremeno.

Osim opisa događaja, Pupin opisuje seoski prostor i domaći inventar kuća kako bi nagovestio koje su društvene vrednosti poštovali njegovi zemljaci i savremenici. U roditeljskoj kući bila je slika Đuzepea 
Garibaldija, na istaknutom i „počasnom” mestu, pored ikone, najvažnije slike u svakoj srpskoj kući. „I sećam se da je u kući moga oca, gde su se održavala ova sela, bila jedna Garibaldijeva slika u boji, sa njegovom crvenom košuljom i šeširem okićenim perjem. Ta je slika visila pored 'ikone', slike našeg sveca” (PuPIN 1929: 10).

Srbi su slavili junake poput italijanskog heroja Đuzepea Garibaldija, u čijem liku su otkrili slobodarski duh poput svog voljenog Karađorđa. „U istoj sobi, na jednom naročito istaknutom mestu, sama za sebe, visila je slika Kara-Đorđeva, vođe srpskog ustanka. U blizini je bila i slika ruskog cara, koji se upravo bio "oslobodio robovanja" (IBID).

Ovaj „prikaz” društvenih vrednosti upotpunjuje isticanje odsustva slike austrijskog cara nakon 1869. godine. Kako je pravda bila vrhovna vrlina, neoprostiva je bila izdaja. Nakon austrijsko-mađarske nagodbe i stvaranja austrougarske monarhije, Graničari su se osećali prevarenim od strane austrijskog cara kome su bili odani. Prezir prema caru zbog „izdaje” bio je neumitan i neupitan, kao jedna od osnovnih kolektivnih vrednosti. Gnev prema izdaji, kao uvreda osećanja pravdoljubivosti bila je kolektivno dobro i kolektiv joj se morao povinovati. Ali, 1869. godine „car je pogazio svoju reč” predavši Granicu Mađarima. Kad je 1869. car ukinuo Vojnu Granicu i „njen narod izručio Madžarima”, Graničari su osetili da su izdani i da je car pogazio svoju reč. Strasno negodovanje zaokupilo je čitav narod. Pupin piše kako mu je otac tada rekao: „Ti ne smeš služiti cara. Car je pogazio svoju reč; u očima Graničara, on je izdajica! Graničari preziru čoveka koji svoju reč ne drži” (IBID). Ovaj događaj odigrao se nakon stvaranja austrougarske monarhije 186\%. prema kojoj je Granica pripala Mađarskoj.

Opis Granice i Graničara upotpunjuje sliku o društvenim vrednostima idvorske zajednice. Graničari su bili seljaci koji su ratovali u austrijskoj vojsci i čuvali spoljene granice monarhije. „Vernost caru”, podseća Pupin, „bila je osnovna vrlina Graničara” (IBID). Srpski seljaci bili su odani vojnici, cenili su pravednu borbu, i čuvali vrhovne vrline slobode, junaštva i istine. Pupin piše, „Austrijski car, kao čuvar njihove slobode, uživao je počasno mesto pored ljudi kao što su bili Kraljević 
Marko, Kara-Đorde, Car Aleksandar Oslobodilac, Linkoln i Garibaldi. Ova su imena bila upisana u 'Knjizi Slave' u Idvoru' (IBID).

U Pupinovim opisima društvene dinamike seoskog života mogla bi se naslutiti uloga pojedinih njegovih članova i grupa. Žene, na primer, nisu imale ulogu u društvenim događajima, istorijskim razmatranjima, niti javnim poslovima. Nisu pominjane na poselima, niti u bilo kakvim javnim okupljanjima u selu. Znanje, istorija i obrazovanje - sve su to bili muški poslovi u Srbiji devetnaestog veka. Žene su medutim imale veliku ulogu u srpskom domu. Iz opisa majke u sećanju mogao bi se naslutiti položaj žena, poštovanje prema njihovoj izvornoj mudrosti uprkos nedostatku obrazovanja.

Majka je bila veoma pobožna, neuka i nepismena. Međutim, iako nije znala „ni da čita ni da piše” (PuPin 1929: 11) kao retko ko, poznavala je i Stari i Novi Zavet. ... stihove iz psalama. Poznavala je životne istorije svetaca, a omiljeni svetac bio joj je Sveti Sava. Pupin ovim nagoveštava čudesan odnos majke prema obrazovanju, njenu zadivljenost prema znanju i saznavanju i važnosti učenja i napredovanja u životu. Bila je svesna svog nedostatka obrazovanja, osećaja da je „slepa kod očiju" i prikraćenosti u životu i kako se usled neukosti ne bi usudila da ode dalje od „atara njihovog sela” (IBID).

Iako nepismena, upravo majka je navela mladog Mihajla na put saznanja i traganja za odgovorima izvan „atara njegovog sela”. Uputila ga je u „važnost svetla” $i$,novog para očiju”. Pupin piše:

Kako se danas sećam, ona bi mi o tome na ovaj način govorila: 'Dete moje, ako želiš da pođeš u svet, o kome si toliko slušao na ovim našim poselima, moraš potražiti još jedan par očiju, oči za čitanje i pisanje. Znanje, to su zlatne lestvice koje nas vode u nebesa; znanje je svetlost koja osvetljava naš put kroz ovaj svet i vodi nas u život budućnosti, pun neuvele slave'. (IBID)

Lik Pupinove majke izgrađen je kao arhetipska figura majke-zaštitnice i učiteljice, glavnog izvora nadahnuća i mudrosti koje je uvek važnije i dublje od praktičnih saznanja koja proizvodi društveni život i nameće svakodnevnica. Ova druga, „površna mudrost” u Pupinovom tekstu oličena je u figuri učitelja. Za razliku od majke, učitelj je robovao stereotipima trenutnih dostignuća nauke i nije uspevao da se vine 
iznad horizonta usvojenih saznanja, odnosno „atara sela”, da se uspne uz „zlatne lestvice ... u budućnost”, poput majke. Naime učitelja Pupin slika kao nekoga ko nije „imao ni pojma o svetu”, ili, kako na drugom mestu kaže, „čitanje, pisanje, računanje, sve to mi se činilo kao sredstvo za mučenje” (PuPIN 1929: 10).

Učitelj je, naime, kao i ostali muški članovi seoske zajednice bio zatomljen u teskobnoj svakodnevnici zabačenog sela, siromašnog života i nevelikih mogućnosti da se vine izvan njenih granica, bilo u geografskom, bilo u saznajnom smislu. Za razliku od majke, nije ga odlikovala vizija svetlosti koju bi znanje moglo da donese. Paradoksalno, međutim, muški članovi seoske zajednice bili su posvećeni istoriji, logici, etici i prenošenju životnih mudrosti na nove generacije seljana. Često se dešavalo, međutim, da je horizont znanja bivao zamagljen sujeverjem. Kao što su Babu Batikina poštovali između ostalog i zbog navodne vidovitosti, seljani su bili skloni da prirodne pojave smatraju voljom nebeskih sila. Pupin pripoveda kako je jedva dočekao da sa ocem i njegovim prijateljima, viđenijim ljudima u selu, podeli svoja prva školska saznanja o poreklu i prirodi električne energije, kao i prirodnim pojavama poput munje i grmljavine. Dočekali su ga sa nevericom i prekorom. Otac je bio ljut, kao i njegovi prijatelji koji su se „zgranjavali od čuda” (Pupin 1929: 12). Bili su uvereni da „taj deran” priča „jeres”. Otac je bio ljut i zbog činjenice da je Mihajlo „zaboravio” da ga je upravo on učio da grmljavina „dolazi usled treske neba pod kolima Svetoga Ilije” (IBID). „Nisam mogao da se ne nasmešim”, kaže Pupin, „pomalo podrugljivo” (IBID). I pored činjenice da je „visoko cenio očevo mišljenje” (IBID), Mihajlo je odlučio da se usprotivi tradicionalnom verovanju „najmudrijih ljudi u Idvoru" (IBID).

Otac, iako kao muški član zajednice viši u društvenoj hijerarhiji, bio je, bar u Mihajlovom sećanju, inferiorniji u odnosu na majku. Otac nije shvatao značaj „novog para očiju”, saznanja, i ispitivanja usvojene slike sveta.

Majka ga je i ovom prilikom „spasla” izbavivši ga iz neprilike. Majka je pronašla način da mudro, i taktično, diskretno i bez prezira pošalje poruku o važnosti sticanja novih znanja; „Majka mu odgovori da, ona nije nigde u Svetom pismu našla potvrdu za tu priču o Svetom 
Iliji, pa je sasvim moguće da je taj Amerikanac Franklin u pravu, a da je lažna ova priča o Svetom Iliji” (Pupin 1929: 13).

Osim instinktivne mudrosti, majka je bila prosvećena svojom žudnjom za znanjem i napredovanjem. Imala je istančan dar za sagledavanje sveta i njegovih nesavršenosti. Majka je umela da se suprotstavi sudbini, da izabere put na koji će usmeriti, suzbivši bol rastanka sa sinom, ispunjavajući drevnu ulogu majke koja „zna i kad ne razume”, poput arhetipa majke u drevnim mitovima o Demetri i Heri. Pupin ne govori o bolu rastanka, gubitku i izmeštenosti koje je morao osećati. Izostavljajući emotivne refleksije i pojedinačne utiske, pripovedač ne daje glas svojim protagonistima. Svi njegovi likovi deo su veće celine Pupinove priče tako što su njihovi pojedinačni glasovi utkani u niti priče i slike o Banatu sagledanom, ispisanom i naslikanom kroz ukrštene prizme iskustva, nostalgije i distance.

U svesti idvorskih seljaka kolektiv je bio važniji od pojedinca. Razmišljanja u svetu bila su u kontekstu kolektivne sudbine, prirodnih sila, sudbine naroda i istorije. Kolektivno osećanje bilo je prisutno u svakodnevnim poslovima kao i u apstraktnim razmišljanjima o životu, porodici, narodu, istoriji i zemlji. Verovatno su od te povezanosti sa zemljom poticali i ostali principi koji su određivali njihov svakodnevni život i definisali njihovu svest. Budući da je Pupinov Idvor živeo od zemljoradnje, život se odvijao u ritmu prirodnih ciklusa setve, žetve i spremanja za zimu. Kao da je za seljane teklo mitsko vreme. To je dodatno obavijalo svest seljana kolektivnim osećanjem. Karl Jung piše na mnogim mestima o tome da plemena imaju kolektivnu svest, upravo zbog neraskidive veze sa zemljom i njenim impulsima, značenjima darovima i nedaćama koje iz tih ritmova proizlaze.

Seljani su u svemu nastupali složno, pomagali jedni drugima u dnevnim poslovima, podržavali i štitili jedni druge od uljeza. „Starac i mladić, čovek i marva” (IBID). Pupin govori o „srpskom volu” gotovo kao o partneru u svakodnevnim dužnostima, čiji životni ritam rada i odmora se gotovo poklapao sa ritmom ljudi koji su „radili” pored njega. Pupin piše: 
Niko ne radi toliko koliko radi srpski vo. On je najverniji i najvažniji sluga srpskog seljaka svuda, a naročito u Banatu. On poore sve njive u proleće; on sveze sazrelo žito sa plodnih polja na seoska guvna, kada dođe vreme žetvi. Tek početak vršidbe završava teške napore dobrog starog vola. (IBID)

Izvesno poštovanje za „dobrog starog vola” poticalo je iz bliskosti, zajedničke teskobe i blagodeti, i zasluženog odmora.

Tada počinje njegov letnji odmor, kada ga šalju na pašu da se prihrani, odmori i pripremi za jesen, kada treba prevlačiti žuti kukuruz i početi jesenje oranje. Seoskim dečacima, još nejakim za rad na guvnu, određuje se da za vreme letnjeg odmora čuvaju volove na paši. Školski odmor i odmor dobroćudnog starog vola tako padaju u isto vreme. (IBID)

Stoka je bila vitalna za očuvanje života i privrede malog banatskog sela. Kako je u seoskom životu svako imao utvrdeno mesto u održavanju dobrobiti zajednice, odrasli, deca i životinje su takođe učestvovali aktivno u svakodnevnim poslovima. Dečacima je povereno noćno čuvanje stoke od kradljivaca. Zbog ovoga su usavršili „pastirsku veštinu”: naročito organizovanu stražu sa jedinstvenim sistemom „dojavljivanja i dozivanja”. Svaki dečak ,imao je bricu, nož sa dugom drvenom drك̌kom koji bi zabadali duboko u zemlju" (IBID). Izgradili su čitav sistem nemušte komunikacije. Udarali bi po drvenoj dršci noža i na taj način određivali međusobnu udaljenost, pravac i upozoravali jedan drugog na opasnost. Otkrili su ubrzo kako da odrede pravac zvuka prislanjajući uvo na zemlju. Uočili su takođe da zvuk putuje brže po ravnoj i tvrdoj zemlji nego po mekoj i uzoranoj. U skladu sa tim otkrićima, organizovali su svoje noćne avanture. Tako su nadmudrili neprijateljelovokradice, „koji su skriveni noću u kukuruzima, [i koji] ne bi mogli čuti ni odrediti od kuda dolazi podzemno dojavljivanje" (IBID). Bile su to prve Pupinove „studije” bežičnog prenosa zvuka na daljinu.

Ova „pastirska veština” govorila je o zajedništvu, poverenju, oštroumnosti i veštini. Pupin piše: „Mi bi se dečaci naročito spremali. Postavili bi se duž jedne linije, otprilike na dvadeset koračaja po jedan. Ta linija je delila pašnjak od kukuruza, bila je naš 'brisani prostor" (IBID). Bili su svesni značaja svog zadatka, važnosti zemlje i stoke u njihovom životu, stoga su zadatak obavljali sa naročitim ponosom, 
koji Pupin nagoveštava jednostavnom jukstapozicijom događaja, lične $\mathrm{i}$ javne istorije, istovremeno podsećajući na sveprisutnost istorije $\mathrm{u}$ duhovnom životu seljana: „Na Verdenu su Francuzi kazali: 'Ovuda ne smeju proći!' To je bilo i naše geslo, a odnosilo se i na naše prijatelje, volove, kao i na naše neprijatelje - ... lopove...." (IBID).

U ovom korisnom poslu pronalazili su ogromno zadovljstvo: „Kada su potpuno jasne i mirne noći u letnje doba u ravnicama moga rodnoga Banata, zvezde su neobično svetle, a nebo, naprotiv, sve je crno" (Pupin 1929: 14). Slika zajedništva i sklada života predstavljena je opisom straže:

Znali smo kada duboko u noć čujemo slabačak glas zvona sa crkve u naselju, oko četiri milje istočno od nas, da preko kukuruza na naš pašnjak dolazi povetarac koji sa mladog kukuruza nosi sladak miris našim gladnim volovima, pozivajući ih na bogatu gozbu u kukuruzima. (IBID)

S druge strane idilične slike balkanskog pejzaža izraz su osećanja topline, nežnosti i ponosa koja prožimaju Pupinovo pripovedanje. Banatski pejzaž, sublimiran u slici,

Svetlost zvezda, mlještanje volova na paši i slabački jecaji dalekog crkvenog zvona bili su znaci prema kojima bi se upravljali tih mračnih letnjih noći, pri čuvanju našeg dragocenog dželepa. (IBID)

U ekfrazama pejzaža i opisima života skrivene su naracije istorije, kulture i shvatanja sveta srpskog društva iz Pupinove vizije u sećanju. Njegove uspomene izbrisale su tegobe i neprilike odrastanja u siromaštvu. Obojene su prikrivenim osećanjima ljubav i blagost, nostalgija i duboko poštovanje prema zemlji iz koje je potekao i u kojoj je boravio u već dalekoj prošlosti.

Došavši u Ameriku, Mihajlo je nastavio da posmatra svet kroz prizmu iskustva koje je stekao u svom rodnom Banatu. Junaci njegovih sećanja, majka, otac, Hajduk Veljko, Čučuk Stana, patrijarhalna zajednica sa jasno utvrđenim rodnim dužnostima, ulogom dece i došljaka, iskustva iz Evrope i kratkotrajnog boravka u Pragu, stvorili su matrice u koje je Mihajlo, kao i svaki čovek pokušao da uklopi sliku sveta koju je ugledao u Americi. U Pupinovu sliku Amerike, ugrađen 
je pogled doseljenika koji je prevalivši mukotrpan put brodom stigao u željeni Njujork. U njegov pogled utkani su čežnja, radoznalost i žudnja putnika koji pokušava da sagleda novu sredinu i stvori svoj prostor u njoj. Pišući o prvim susretima sa građanima Njujorka i mesta na kojima je tražio posao, opisuje životne teškoće i sitne radosti kao i smicalice koje su čekale svakog novajliju i došljaka.

Pupin opisuje sliku užurbanog Njujorka sa „hiljadama telegrafskih žica razapetih preko ulice između zgrada, kao paukova mreža” (Pupin 1929: 28). Piše kako se u „košnici zvanoj Brodvej” obreo noseći i dalje crveni fes na glavi, tako da je i likom odavao došljaka koji je upravo stigao izdaleka. Zatim, kako je primetio da su „deca koja su prodavala novine i čistila cipele, [želela] da se malo prošegače na [njegov] račun” (IBID). Bio je svestan kad su se „podgurkivala” da se „smeju” prizoru njegove neuklopljenosti u sliku Njujorka,

Svoj položaj došljaka Pupin je hrabro podnosio imajući na umu reči drugih putnika na useljeničkom brodu, „ma ko ti bio, ma što znao i imao, bićeš ‘grinhorn’ (došljak,) kada prispeš u Ameriku” (Ibid). Rekli su mu takođe i da u Americi nije presudno „ko si i šta si, šta znaš i imaš; kada se iskrcaš u Novom Svetu ti si ,grinhorn”; a ,grinhorn” mora da odsluži svoj šegrtski rok pre no što mu se priznaju znanje i umenje" (PuPIN 1929: 24). Pošto je Mihajlo bio bez ikakvog zanata, ova situacija ga je uplašila. Ubrzo je, međutim, shvatio da da je ovo samo delimično istina. Prijatelj koga je ubrzo stekao, Nemac Kristijan, kad je čuo za ove reči upozorenja, odvratio je da mu je tako nešto mogao reći samo „evropski grinhorn”. Naime, dok u Evropi došljaci teško i sporo menjaju svoj položaj dok „si u Americi 'grinhorn' samo dotle dokle sam [veruješ] da [si] 'grinhorn”' (PuPIN 1929: 38).

U druženju sa Kristijanom shvatio je da je u Americi vera u sopstveni uspeh najjača karta za uspeh. Njegov novi prijatelj podsticao ga je da, iako potpuno neuk u molerskim poslovima, prihvati, a zatim prigrli zanat bojenja i oblepljivanja zidova papirom, uveravajući ga da je „ispekao zanat.” Mihajlo se vajkao (Pupin 1929: 37): „To mi je davalo mnogo poleta." Kristijanovi stavovi bili su za Mihajla novi, neprocenjivi ugao posmatranja stvarnosti. 
On je držao da svaki dečko, ako samo pokuša, može sve brzo naučiti; ... I kada sam ga posmatrao na radu u njegovoj maloj stolarskoj radionici u Hobokenu, iskreno sam verovao da on je sposoban za svaki rad. Imao je i jednu mašinu za glačanje drveta i upravo stručnjački je obrađivao drvo i metal, i ako nikad nije bio šegrt. (PuPIN 1929: 37)

Među vinjetama koje slikaju uobičajene dogodovštine novajlije koji je bez novca i prinuđen da se bavi čudnovatim poslovima, na farmi, u pekari, na brodogradilištu, u luci i prihvati iz velike potrebe za novcem bez razmišljanja svaki posao, izdvaja se priča o poslu na farmi u Delaveru. Posao je, između ostalog, uključivao mužu. To je međutim, za Mihajla bilo neprihvatljivo, bez obzira na neophodnost bilo kakvog posla. Pupin piše: „Kad mi reče da ću morati još i krave musti, odbih tu ponudu. Po našem srpskom shvatanju, muženje krava ženski je posao" (PuPIN 1929: 29). Ipak, Pupin je otišao na farmu, ali na drugi posao, koji je podrazumevao da „pazi na dve mazge u toku proletnjih poslova” (IBID). Ovo je rado prihvatio smatrajući da zna „sve što je potrebno znati oko tegleće marve" (IBID). Ispostavilo se sasvim suprotno, staranje o mazgama bio je težak posao, dok se na američkoj farmi mužom nisu bavile žene. Jer iako je na posedu na kome se obreo „svakog dana muženo preko sto krava, nikad ne primetih ni jednu žensku ni u košarama, niti pak u ogromnom mlekaru" (PupIN 1929: 32).

Farma je bila pravo ogledalo američke zajednice i prilika za upoređivanje društvenih razlka. Ova razlika u društvenoj organizaciji bila je prvo veliko razmimoilaženje u običajima na koje je Pupin naišao u novoj sredini. U preklapanju slika farme iz Delavera i idvorske poljoprivredne zajednice, neprestanim upoređivanjem običaja i načina života, Pupin gradi novi pogled na svet.

O američkom društvu, nazorima, rodnim ulogama, obrazovanja, porodice i ostalih klasa i članova najviše je naučio od porodice nastojnika farme. Nastojnikova ćerka ubrzo je postala njegov prvi odani prijatelj, njegova „Vila”. „Ako je ikad bilo vila, pomislih ja tada, prava vila je ova mlada devojčica ovde” (PuPIN 1929: 30). Ime „vila” dao joj je u skladu sa svojim odgojem na srpskim narodnim pesmama u kojima mlada srpska vila igra izvanrednu ulogu. Usvojeni obrazac prati ga i 
sebe vidi kao ,junaka”, poput junaka junačkih pesama, „koji uživa naklonost vile” (IBID) i koja ga štiti i čuva od „zle kobi”.

„Vila” koja, „čuje i najnečujnije glasove, da vidi u najmračnijoj noći, i da, kao prava vila, oseća ne samo najlakše povetarce nego i misli onih koji su oko nje" (IBID), predstavlja junaka ove priče, Pupinapripovedača, kao tragača, spremnog, veštog i hrabrog koji je, uprkos preprekama i upravo zbog njih odlučan da opstane na putu izazova. „Njegova” vila je bila „nežna, vedra i plava, nalik anđeoskim bićima iz mašte junaka sa kojima se nesvesno poistovetio. Imala je natprirodne moći da „shvati bez reči”. I budući da je bila vila, bar u mašti mladog Mihajla, iako se nisu razumeli rečima, jer nisu govorili nijedan zajednički jezik, ona mu je pružila papir, shvativši njegovu želju da piše majci. Njegove molbe „natprirodnim silama” bile su uslišene: „To veče pisao sam majci. To sam želeo, i tu želju moja vila je pročitala na mom licu" (IBID). Ova epizoda u sećanju govorila je o jednom od prvih momenata prisnosti sa novim tlom, novim narodom i novim životom.

Život u porodici nastojnika farme, pažnja sa kojom su ga slušali i uvažavanje sa kojim su ga primali, naslikali su prvu i najupečatljiviju sliku Amerike u očima mladog doseljenika. Od njih je učio engleski i od njih je stekao prve lekcije o životu u američkom društvu, o rodnim, radnim i obrazovnim odnosima, i istoriji. Stekao priliku da bude prihvaćen kao ravnopravni govornik i građanin dok su vodili razgovore u toku kojih bi se „vila pretvorila sva u uho” (IBID).

Domaćini su sa zanimanjem slušali priče o Idvoru. Želeli su da upoznaju Mihajla, njegov život i navike. To ga je dirnulo i još čvršće vezalo za novi svet. Pupin piše:

Domaćica nastojnikova često me je pozivala da o večeri ostanem u njihovom porodičnom krugu. Rekoše mi da ih mnogo zanimaju moje pričo o Idvoru, Pančevu, Pešti, Pragu, Hamburgu i doseljeničkom brodu. (PuPin 1929: 31)

Mladi doseljenik Pupin, kao svaki tragač, žarko je želeo pohvalu svoje Vile koja ga je učila engleskoj gramatici i izgovoru tako da mu je „najveća žudnja bila [...] da dokažem da sam zaslužio titulu 'smart', koju mi je ona dala” (IBID). Drugom prilikom, Vila i njena majka su mu objasnile „veliku zavrzlamu” oko muže krava. Pupin piše: 
Onda mi protumači položaj američke žene: ona je vaspitač i duhovni vođa pokolenja koja dolaze. Pri tom mi ukaza na činjenicu da u Americi po osnovnim školama ogromnu većinu učitelja sačinjavaju žene. Ovo me obaveštenje začudi i svide mi se, jer sam znao da je moja majka bila bolji učitelj od moga učitelja u školi, jednog starca sa smešnim izgovorom kroz nos. (PuPIN 1929: 32)

Postepeno upoznajući američko društvo, Mihajlo uočava sve dublje razlike u odnosu na svoje rodno selo. Društvena hijerarhija bila je drugačija i ta činjenica u najvećoj meri uslovljavala je potpuno drugačiju komunikaciju među predstavnicima društvene zajednice. Prijateljski odnosi među ljudima bili su zasnovani na ravnopravnom razgovoru između predstavnika raznih generacija i klasa, starosedelaca i došljaka, bili su mu čudni i primao ih je isprva snebivajući se, a kasnije razdragano, sa zadovoljstvom. Opis jedne nedelje koju je proveo sa nastojnikovom porodicom govori upravo o tome. Ovaj događaj je počeo zajedničkim odlaskom na nedeljnu službu u lokalnu crkvu:

Na izlasku pred crkvom sačeka me Vilina porodica i pozva me da se s njima povezem kući. Izgledalo mi je malo čudnovato da se jedan sluga vozi na lepim kolima sa gospodarem, pa umolih da me izvine, ali oni ne pristadoše na to. Nijedan gazda u mom Idvoru ne bi tako radio. Ali, tom pogledu svidoše mi se ovi delaverski ratari sa ovim svojim američkim pojmovima. Štaviše bio je pozvan i na nedeljni ručak u nastojnikovu kuću. Tako je na delu htela da pokaže ono što mi je propovedala o duhovnoj misiji američke žene. (PuPIN 1929: 32)

I tako gradeći svoje novo iskustvo stvarnosti na brisanom prostoru između dve kulture, srpske i američke, koje su iako posmatrane u istom istorijskom trenutku, stvarale radikalno drugačije slike stvarnosti, Pupin je neprestano upoređivao i tako stvarao koordinate svog sveta, svoju mapu stvarnosti, na kojoj su Amerika i Srbija bile označene sećanjima i iščekivanjima. U razgovoru sa svojim domaćinima Pupin je i sam slikao u svesti srpsko društvo u odnosu na američko, shvatajući razlike i sublimirajući ih u slike o dve kulture. Razlika u društvenom miljeu poticala je iz razlike u načinu života, imovinskom stanju i istorijskoj stvarnosti Srbije i, napokon šire Evrope i Amerike toga doba. Jer, zapažao je Mihajlo, „kad bi Vila bila prinuđena da radi oko krava 
i u mlekari, ko bi onda mene učio engleski” (IBID). Postavljajući ovu sliku američke situacije naspram evopske i, nadasve srpske, Pupin je izvodio zaključke poput, „najjači i najsposobniji ljudi u Evropi provode veći deo svoga života na bojištima i vežbama za ratovanje; ovo naročito vredi za srpski narod" (Pupin 1929: 33), stoga, smatra Pupin da je upravo to „ono što nagoni srpsku ženu da obavlja po neki teži posao, koji bi inače radili ljudi” (IBID).

Kako u mirnodopskim tako i u ratnim uslovima žena je u Srbiji bila potpora muškarčevim naporima da održi ubogi život i zemlju i to je istina koju je Mihajlo pokušavao da u priči prenese domaćinima:

Tu mi se pružila zgodna prilika da kažem koju više u prilog duhovnog upliva, koji srpska žena vrši na naš narodni život, opisujući položaj srpske žene onako kako ga pretstavljaju srpske narodne pesme o Čučuk Stani, ženi Hajduk Veljka, koja je potsticala svoga junačkog muža da i pogine pre nego da napusti istočnu granicu Srbije, koju je on, za vreme srpske revolucije, branio od ogromno većih turskih sila. Pričao sam joj o Kosovci Devojci, koja je, uprkos opasnosti da pogine ili bude zarobljena, pošla na Kosovo Polje da pruži poslednju duhovnu pomoć junacima na umoru. O Jevrosimi, majci Kraljevića Marka, nacionalnog junaka srpske rase, čiji su saveti i upute bili jedina zvezda vodilja Markova kroz njegov buran život. (IBID)

Sasvim u skladu sa Mihajlovom slikom o blagonaklonosti i ljubaznosti Amerikanaca na koje je nailazio, Vila je sa svoje strane spremno i predusretljivo nastojala da pronađe zajedničku duhovnu nit između spske i američke slike o ženama, jer, smatrala je Vila, ,da je i Amerika, kao i Srbija, bila zemlja junaka” (IBID). Vila je nastojala da „prevede” Mihajlovo drugačije iskustvo sveta na sebi bliske pojmove upoređujući srpsku situaciju sa američkom, sa svojim iskustvom života, jer poistovećivanje je najlakši i najbrži način razumevanja, možda i jedini. Ovako bi Vila govorila o vojničkim temama kod Srba i Amerikanaca:

Upita me: da li sam ja ikad čuo za Martu Vašington, suprugu Džordža Vašingtona, američkog narodnog heroja? [...] „I Vašington, ” reče ona, „kao i Hajduk Veljko, bio je gotov da žrtvuje svoj život, pri prelasku preko podmuklog leda na zahuktanom Delaveru, samo da stigne na vreme i izvrši napad koji je spasao njegovu otadžbinu." I, kako reče, ona veruje da se u tom teškom času Marta Vašington ponela kao i Čučuk Stana. Od tog dana 
Vašington je bio u mojim očima američki Hajduk Veljko, a reka Delaver ulivala mi je uvek duboko poštovanje. (IBID)

Imajući uvek na umu Kristijanove reči da „mladi čovek u Americi može u svemu uspeti, samo ako „ima volje da pokuša” (Pupin 1929: 41), Mihajlo je sledio svoj „američki san”, oslanjajući se na svoju pamet i menjajući svoju sliku o svetu u skladu sa znanjem i iskustvom koje je sticao. Ipak, glavno je bilo obećanje dato majci, „da će joj se skoro vratiti obogaćen znanjem i akademskim počastima” često je sebi govorio (IBID). Taj san me potseti da je to moje obećanje brižljivo ubeleženo u mojoj potsvesti" (IBID).

Sledeći svoj san o napretku, obreo se u Prinstonu, na pragu svog budućeg poziva. U prvom susretu sa čuvenim univerzitetom Prinston, njegova slika o akademskom životu bila je tek u povoju. Brusio ju je na osnovu mudrosti i iskustva sveta koje je nosio u sebi i kao i sve ostalo oko sebe posmatrao kroz naočare srpske tradicije i učenja iz detinjstva. Bio je zadivljen Prinstonom, koji „nije ličio ni na što što [je] video do tada” (PuPin 1929: 41).

Čitao sam o Hilandaru, proslavljenom manastiru na Svetoj Gori, na Jegejskom Moru, koji je osnovao Sveti Sava u dvanajestom stoleću. Gledao sam slike tih zgrada, u kojima su kaluđeri živeli u samoći i učenju. Pa mi se činjaše da je jedno takvo mesto i Princeton sa svojim mnogim zgradama koje liče na manastire. Tu se mladićima pružaju sve prilike da uče i postanu ljudi od nauke, tako da budu sposobni da život svoj posvete onom radu kome je Sveti Sava svoj život posvetio. (IBID)

Tu u Prinstonu upozao je studenta koji je „znao mnogo o Srbiji, pa i o Srbima u Austro-Ugarskoj" (IBID). Kada mu je Mihajlo poverio da je u Ameriku došao da „traži znanja”, izrazio je želju da ga jednog dana vidi kao studenta upravo tu na Prinstonu. Mihajlu je to izgledalo nemoguće, iako je „student” iskreno govorio iz sopstvenog uverenja da svako može uspeti ako uloži trud i „ima volje”. Upoređujući svoje dve slike sveta svesno i nesvesno koje su ga u ovoj situaciji navele na razmišljanje o dostupnosti elitnih krugova u Evropi i Americi, Mihajlo se vajkao: „Izgledalo je nemoguće da se sa onim đacima, koji su na sebi imali nečeg plemićkog, svrsta jedno srpsko seljače. Evropski aristokrat ne bi mi nikad tako što spomenuo" (PuPIN 1929: 43). Bio je to još 
jedan dokaz u nizu svakodnevnih događaja koji su ga uveravali da je u Americi uspeh dostupan svima.

Pupin je uz pomoć poznanstava i saznanja koja je sticao radeći, šegrtujući i učeći u Americi i o Americi počeo „dizati onaj most koji bi premostio ovaj veliki jaz” (PuPIN 1929: 59) između „useljenika”, „srpskog seljačeta” i ljudi koje je sretao u novoj zemlji. Postao je svestan potrebe da svoju sliku sveta obogati saznanjima koja je crpeo iz američkog iskustva. Sećajući se na koji način se tradicija doživljava u njegovom rodnom Idvoru, u kome se generacije odgajaju na nepromenljivoj slici sveta i života, razumeo je da se našao u sredini koja nudi i očekuje drugačiji kredo. Dobro se sećao da je njegovo „rodno mesto polagalo mnogo na svoje tradicije, i ja sam znao kako bi se idvorski seljaci bunili protiv toga da se u njihovom istorijskom selu nastani neki stranac, čije bi ponašanje odskakalo od onoga što je kod njih bilo uobičajeno." (Pupin 2018: 59). Pa ipak, radovao se spoznaji da u njegovom novom svetu on, „srpsko seljače”, ima mogućnost da postane deo američke tradicije upravo svojim položajem useljenika, „grinhorna”, i upravo zbog svoje odlučnosti da uči i ostvari svoj san. Bio je takođe spreman da svoju srpsku ili, šire evropsku ideju o važnosti tradicije izmeni u skladu sa tim novim shvatanjem tradicije, anglosaksonskim, o kome Eliot piše u čuvenom eseju „Tradicija i individualni talenat”, tradicije koja je u neprestanoj promeni, koja je istovremeno dopunjuje i obnavlja. Razumeo je da je takvo shvatanje tradicije ključno za prihvatanje nove slike sveta.

Ali glavna sadržina moga iskustva za vreme mojih „grinhornskih” godina, uverila me je: da postoje izvesne velike amerikanske tradicije i da se sreća u ovoj zemlji krije od onih useljenika, [...] koji nisu u stanju da shvate značenje i značaj tih tradicija u amerikanskom životu. (PuPIN 1929: 60)

Slika „američkog sna” o mogućnosti izmene svoje životne situacije na osnovu postignuća i verovanja u uspeh u koji su ga uputili Kristijan i Vila, pružala se pred mladim Pupinom poput novog prostora čiji horizont nije mogao sagledati. Značaj njihovog prijateljstva nikad nije zaboravio. Kasnije, sećajući ih se, shvatao je koliko su doprineli njegovom uspehu u novoj otadžbini. 
Majka moje Vile na poljskom dobru u Delaveru, moji doživljaji sa Kristijanom iz Zapadne Ulice, pa Džimove male predike u ložionici u, ulici Kortland, sve je to duboko u moju dušu uklesalo tu misao. Duhovno raspoloženje jednog srpskog mladića iz Vojne Granice bilo je vrlo prijemčivo za utiske te vrste. (IBID)

Uporedne slike dve otadžbine obogatile su Mihajlovo iskustvo sveta. One se nisu potirale, već su se dopunjavale. Na mnogim mestima $\mathrm{Pu}^{-}$ pin izjavljuje da je jezik koji je naučio u detinjstvu bio uvek njegova vodilja kroz iskustva i izazove života. „Poštovanje tradicija moga naroda naučilo me je da s poštom pristupam tradicijama zemlje, od koje očekivah da mi bude druga otadžbina”. (IBID)

Generičke odlike autobiografskog žanra nalažu da autor iznese svoja sećanja. Ipak Pupinovo delo je mnogo više od jednostavne memoarske literature. Fikcionalizacija događaja iz sećanja prikazuje svest, razmišljanja, predviđanja, i dramu opstanka koja je opisivala život i duh male idvorske zajednice u Banatu sa kraja devetnaestog veka. Pominjanje istorijskih događaja pruža kontekst ličnim zapažanjima i iskustvima o kojima Pupin piše. Na taj način Pupinova autobiografija najavljuje neke kasnije pravce razvoja personalnog teksta. Čitajući ovaj tekst koji je nastao na početku dvadesetog veka, čitaocu se nameće pitanje koje će sebi postaviti francuski književnik Serž Dubrovski nekoliko decenija kasnije. Da li je personalni tekst samo memoarska literatura i da li autobiografija crpe značenja prevashodno iz (sopstvenog) sećanja?

Dubrovski 1977. godine definiše autofikciju, opisujući ovaj žanr kao različit u odnosu na klasičnu autobiografiju. Prema Dubrovskom, naime, autofikcija se poput autobiografije temelji na „strogo stvarnim događajima i činjenicama”, ali predstavlja prenošenje „govora o avanturi u avanturu govora”. Drugim rečima, novo shvatanje personalnog teksta podrazumevalo je fikcionalizaciju likova, pripovedača i autora teksta. Novi personalni tekst uspostavlja prostor na kome se preklapaju pojedinačno i opšte. Lična proza obuhvatila bi na taj način istine drugih pojedinaca i društvenih grupa. Sasvim u skladu sa ovom narativnom logikom je pripovedač Pupinovog personalnog teksta koji daje glas grupama ljudi iz svog okruženja, od seoskog učitelja i guslara 
u Banatu do „grinhorna” u novoj otadžbini, preko članova američkog društva, do američkih žena sa kraja devetnaestog i početka dvadesetog veka. Protagonista Pupinovog dela je takođe i predstavnik socijalne klase - seljaka, iseljenika, doseljenika, posmatrača, građana sveta, i nadasve hibridnih identiteta. Govoreći u ime svih ovih grupa ljudi na međunarodnoj istorijskoj pozornici svog vremena, Pupin u svom personalnom tekstu, svojoj autobiografiji, sakuplja čitav niz značenja istorije i kulture dvadesetog veka - veka čestih promena, seoba i velikih otkrića, pojava koje je najavio i u kojima je i sam učestvovao.

Slike domovina nastaju tako na svesnom, iskustvenom i nesvesnom, unutrašnjem planu kao proizvod preispitivanja, modeliranja, novih saznanja i preklapanja sa novim slikama i vizijama. Pupin je crpeo iz obe ove vizije i kao dokaz te hibridnosti jeste i ime koje sebi dao i kojim se u najvećem delu života predstavljao, kombinacija njegova „dva porekla” - Michael Idvorski Pupin.

\section{CitiRANA LITERATURA}

Внавна, Homi. "The World and the Home", Social Text, No. 31/32, 1992, $141-153$.

Doubrovsky, Serge. Fils, Paris: Galilée, $197 \%$.

PuPIN, Mihajlo Idvorski. Sa pašnjaka do naučenjaka. Veliki Bečkerek: Matica srpska, 1929.

RusHDIE, Salman. "Imaginary Homelands" in Imaginary Homelands, London: Granta, 1991, 9-21. 
Aleksandra V. Jovanović

\section{MIHAJLO PUPIN: TRAVELLER, WRITER AND INNOVATOR}

\section{Summary}

An exceptional scientist of Serbian descent, Mihajlo Pupin immigrated into the US in 18\%4. Apart from his scientific achievements, especially in the field of telecommunications, and the job of a professor at Columbia University in New York, he was an important writer. Pupin was awarded the prestigious Pulitzer Prize for autobiography for his work From Immigrant to Inventor in 1924. The Pulitzer Prize is one of the major prizes in the US which has been annually awarded since 1917 for literature, drama and music. The present study deals with Pupin's autobiography in the context of his life journey, which encompasses his three life adventures: of an immigrant, scientist and writer. Further, it aims to analyze the text of Pupin's autobiography as a work of autofiction. This latter-day style of personal writing offers Pupin a useful framework in which he could imagine juxtaposed images of his two homelands, Serbia and America.

Keywords: Banat, America, science, sound, "greenhorn", identity, hybridity, autofiction.

Univerzitet u Beogradu

Filološki fakultet

ningi@sbb.rs 